proximal tubular reabsorption of sodium which is thought to cause the hypertension..$^{45}$

Canessa and her colleagues first reported increased maximal rates of $\mathrm{Na}^{+} / \mathrm{Li}^{+}$countertransport in erythrocytes from some patients with essential hypertension. ${ }^{46}$ This has been confirmed, although abnormalities are hardly evident in hypertensive women ${ }^{47}$ and blacks, ${ }^{48}$ and body weight seems to have an effect in its own right. ${ }^{49}{ }^{50}$ Lithium is not a natural substrate of the exchanger, which may function normally in a $\mathrm{Na} / \mathrm{Na}^{+}$or $\mathrm{Na}^{+} / \mathrm{H}^{+}$mode. The $\mathrm{Na}^{+} / \mathrm{H}^{+}$antiport is well characterised: it is inhibited by amiloride, helps regulate intracellular $\mathrm{pH}$, and promotes cell growth. ${ }^{51-53}$ If $\mathrm{Na}^{+} / \mathrm{Li}^{+}$ exchange in erythrocytes is equivalent to $\mathrm{Na}^{+} / \mathrm{H}^{+}$exchange, which is uncertain, ${ }^{5455}$ then increased $\mathrm{Na}^{+} / \mathrm{H}^{+}$exchange might be linked to the pathogenesis of hypertension in two ways: overactivity of the exchanger in the proximal renal tubule might cause sodium retention ${ }^{5356}$; or overactivity in the erythrocyte might be a manifestation of increased growth factor activity causing hyperplasia or hypertrophy of vascular smooth muscle and hence increased vascular resistance. ${ }^{57}$

Studying sodium transport across the cell membrane has given at best tantalising glimpses of the mechanisms in hypertension. We need to know more about these transporters in the myocytes of resistance vessels and more about their relation to transporters in blood cells.

Peter F Semple

Consultant physician ANTHONY F LEVER

Medical Research Council Blood Pressure Unit,

Western Infirmary,

Glasgow G11 6NT

1 Friedman SM. Cellular ionic perturbations in hypertension. Fournal of Hypertension 1983;1: 109-14.

2 Jones AW. Altered ion transport in vascular smooth muscle from spontaneously hypertensive rats. Circ Res 1973;33:563-71.

3 Jones AW. Ionic dysfunction and hypertension. Advances in Microcirculation 1982;11:134-59.

4 Hermsmeyer K. Altered arterial muscle ion transport mechanism in the spontaneously Hermsmeyer K. Altered arterial muscle ion transport
hypertensive rat. I Cardiovasc Pharmacol 1984;6:510-5.

hypertensive rat. 7 Cardiovasc Pharmacol 1984;6:510-5.
5 Stekiel WJ, Contney SJ, Lombard JH. Small vessel membrane potential, sympathetic input, and Stekiel WJ, Contney SJ, Lombard JH. Small vessel membrane pote
electrogenic pump rate in SHR. Am f Physiol 1986;250:C547-56.

6 Garay R, Dagher G, Pernollet M-G, Devynck M-A, Meyer P. Inherited defect in a $\mathrm{Na}^{+}, \mathrm{K}^{+}$cotransport system in erythrocytes from essential hypertensive patients. Nature 1980;284:281-3.

7 Postnov YV, Orlov SN, Shevchenko A, Adler AM. Altered sodium permeability, calcium binding and Na-K-ATPase activity in the red blood cell membrane of essential hypertension. Pfiugers Archiv 1977;371:263-9.

8 Woods KL, Beevers DG, West M. Familial abnormality of erythrocyte cation transport in essential hypertension. BrMed f 1981;282:1186-8.

9 Wambach G, Helber A, Bonner G, Hummerich W, Konrads A, Kaufman W. Sodium-potassium dependent-ATPase activity in erythrocyte ghosts of patients with primary and secondary hypertension. Clin Sci 1980;59(suppl): 183-5.

10 Bin Talib HK, Chipperfield AR, Semple PF. Potassium influx into erythrocytes in essential hypertension. Foumal of Hypertension 1984;2:405-9.

11 Boon NA, Aronson JK, Hallis KF, Grahame-Smith DG. Cation transport abnormalities in vivo in untreated essential hypertension. Clin Sci 1986;70:611-6.

12 Weissberg PL, Weaver J, Woods KL, West MJ, Beevers DG. Pregnancy induced hypertension: evidence for increased cell membrane permeability to sodium. Br Med f 1983;287:709-11.

13 Walter V, Distler A. Abnormal sodium efflux in erythrocytes of patients with essential hypertension. Hypertension 1982;4:205-10.

14 Parker JC, Berkowitz LR. Physiologically instructive genetic variants involving the human red cell membrane. Physiol Rev 1983;63:261-313.

15 Hilton PJ. Cellular sodium transport in essential hypertension. $N$ Engl f Med 1986;314:222-9.

6 Simon G, Conklin DJ. In vivo erythrocyte sodium concentrations in human hypertension is reduced not increased. Joumal of Hypertension 1986;4:71-5.

17 Edmondson RPS, Thomas RD, Hilton PJ, Patrick J, Jones NF. Abnormal leucocyte composition and sodium transport in essential hypertension. Lancet 1975; i: 1003-5.

18 Ambrosioni E, Costa FV, Montebugnoli L, Tartagni F, Magnani B. Increased intralymphocytic sodium content in essential hypertension: an index of impaired $\mathrm{Na}^{+}$cellular metabolism. Clin Sci $1981 ; 61: 181-6$.

19 Heagerty AM, Milner M, Bing RF, Thurston H, Swales JD. Leucocyte membrane sodium transport in normotensive populations: dissociation of abnormalities of sodium efflux from raised blood pressure. Lancet 1982;ii:894-6.

$20 \mathrm{Gray} \mathrm{HH}$, Johnson VE, Poston L, Hilton PJ. Sodium transport by leucocytes and erythrocytes in hypertensive patients and their normotensive relatives. Foumal of Hypertension 1984;2:467-9.

21 Chien Y, Zhao G. Abnormal leucocyte sodium transport in Chinese patients with essential Chien Y, Zhao G. Abnormal leucocyte sodium transport in Chinese patients with esse
hypertension and their normotensive offsprings. Clin Exp Hypertens [A] 1984;6:2279-96.

hypertension and their normotensive offsprings. Clin $\operatorname{Exp} H y$ pertens $[A]$ 1984;6:2279-96.
22 Watt G. Design and interpretation of studies comparing individuals with and without a family Watt $\mathrm{G}$. Design and interpretation of studies comparing individuals
history of high blood pressure. Foumal of Hypertension 1986;4:1-7.

23 Aalkjaer C, Heagerty AM, Parrin SD, Bell PRF, Bing RF, Swales JD. Cell membrane sodium transport-a correlation between human resistance vessels and leucocytes. Lancet 1986; ; 649-51.

24 Tobian L, Binton JT. Tissue cations and water in arterial hypertension. Circulation 1952;5:754-8.
25 Aalkjaer C, Kjeldsen K, Norgaard A, Clausen T, Mulvany MJ. Oubain binding and $\mathrm{Na}^{+}$content in resistance vessels and skeletal muscles of spontaneously hypertensive rats and $\mathrm{K}^{+}$deple Pike MM, Fussel ET, Smith TW, Springer CS. High resolution ${ }^{23} \mathrm{Na}-\mathrm{NMR}$ studies of hur erythrocytes: use of aqueous shift reagents. Am $\mathcal{J}$ Physiol 1984;246:C528-36.

27 de Wardener HE, MacGregor GA. Dahl's hypothesis that a saluretic substance may be responsible for a sustained rise in arterial pressure: its possible role in essential hypertension. Kidney tn

28 Poston L, Sewell RB, Wilkinson SP, et al. Evidence for a circulating sodium transport inhibito $\overline{\bar{D}}$. essential hypertension. BrMed f 1981;282:847-9.

29 Hamlyn JM, Ringel R, Schaeffer J, et al. A circulating inhibitor of $\left(\mathrm{Na}^{+}+\mathrm{K}^{+}\right)$ATPase associaged with essential hypertension. Nature 1982;300:650-2.

30 Gray HM, Hilton PJ, Richardson PJ. Effect of serum from patients with essential hypertension sodium transport in normal leucocytes. Clin Sci 1986;70:583-6.

31 Haddy FJ. Abnormalities of membrane transport in hypertension. Hypertension 1983;5(supi V):66-72.

32 Sagnella GA, Nolan DA, Shore AC, MacGregor GA. Effects of synthetic atrial natriuretic peptifes on sodium-potassium transport in human erythrocytes. Clin Sci 1985;69:223-6.

33 Niggli V, Adurgah ES, Penniston JT, Carafoli E. Purified $\left(\mathrm{Ca}^{2+}+\mathrm{Mg}^{2++}\right)$ ATPase of erythrocyte membrane. Reconstitution and effects of calmodulin and phospholipids. $\mathcal{F}$ 具 Chem 1981;256:395-401.

34 Simmons DA, Kern EFO, Winegrad AI, Martin DB. Basal phosphatidylinosital turnog̈r controls aortic $\mathrm{Na}^{+} / \mathrm{K}^{+}$ATP-ase activity. I Clin Invest 1986;77:503-13.

35 Swales JD. Abnormal ion transport by cell membranes in hypertension. In: de John W, Handbook of hypertension. Vol 1. Amsterdam: Elsevier, 1983:239-66.

36 Reuter $\mathrm{H}$, Seitz $\mathrm{N}$. The dependence of calcium efflux from cardiac muscle on temperature $\overrightarrow{\mathrm{m}}$ external ion composition. F Physiol (Lond) 1968;195:451-70.

37 Kimura J, Noma A, Irisawah H. Na-Ca exchange current in mammalian heart cells. Nalux 1985;319:596-7.

38 Brading AF, Lategan TW. Na-Ca exchange in vascular smooth muscle. fournal of Hypertensigan 1985;3:109-16.

39 Mulvany MJ, Nilsson H, Flatman JA, Korsgaard N. Potentiating and depressing effects ouabain and potassium free solutions on rat mesenteric resistance vessels. Circ Res 1982; 5 :
514-24.

40 Robinson BF, Phillips RJW, Wilson PN, Chiodini PL. Effects of local infusion of ouabain. human forearm vascular resistance and on response to potassium, verapamil and sodiog nitroprusside. Foumal of Hypertension 1983;1:165-9.

41 Mulvany MJ. Changes in sodium pump activity and vascular contraction. Joumal of Hypertension 1985;3:429-36.

42 Hermsmeyer K, Hanler D. Membrane ATPase mechanism of $\mathrm{K}^{+}$-return relaxation in arte muscles of stroke-prone SHR and WKY. Am 7 Physiol 1986;250:C557-62.

43 Garray RP, Meyer P. A new test showing abnormal net $\mathrm{Na}^{+}$and $\mathrm{K}^{+}$fluxes in the erythrocyte essential hypertensive patients. Lancet 1979;i:349-53.

44 Duhm J, Gobel BO. Role of the furosemide-sensitive Na $/ \mathrm{K}^{+}$transport system in determining the steady state $\mathrm{Na}^{+}$and $\mathrm{K}^{+}$content and volume of human erythrocytes in vitro and in vio. steady state $\mathrm{Na}^{+}$and $\mathrm{K}^{+}$content and volume of human erythrocytes in vitro and in vio

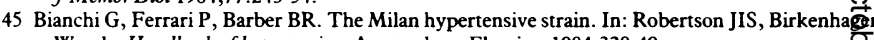
W, eds. Handbook of hypertension. Amsterdam: Elsevier, 1984:328-49.

46 Canessa M, Adragna N, Solomon HS, Connolly TM, Tosteson DC. Increased sodium-lithinum countertransport in red cells of patients with essential hypertension. $N$ Engl $\mathcal{F}$ Mted 1980;302:772-6.

47 Ibsen KK, Jensen HA, Wieth JO, Funder J. Essential hypertension: sodium-lithium coun transport in erythrocytes from patients and from children having one hypertensive paren Hypertension 1982;4:703-9.

48 Canessa $M$, Spalvins A, Adragna N, Falkner $B$. Red cell sodium countertransport and cotranspe in normotensive and hypertensive blacks. Hypertension 1984;6:344-51.

49 Cooper R, Trevison M, Ostrow D, Simpos C, Stamler J. Blood pressure and sodium lithi蚫 countertransport: finding in population-based surveys. Foumal of Hypertension 1984;2:467-

50 Hunt SC, Williams RR, Smith JB, Ash KO. Associations of three erythrocyte cation transpof systems with plasma lipids in Utah subjects. Hypertension 1986.8:30-6. 51 Moolenaar WH, Tsien RY, ven der Saag PT, de Leat SW. $\mathrm{Na}^{+} / \mathrm{H}^{+}$exchange and cytoplasmic

52 L'Allemain G, Franchi A, Cragoe E, Jr. Blockade of the $\mathrm{Na}^{+}$antiport abolishes growth facto induced DNA synthesis in fibroblasts. Structure-activity relationships in the amiloride series. 7 Biol Chem 1984;259:4313-9.

53 Mahnensmith RL, Aronson PS. The plasma membrane sodium-hydrogen exchanger and its rigle in physiological and pathophysiological processes. Circ Res 1985;56:773-88.

54 Escobales N, Canessa $M$. Amiloride-sensitive $\mathrm{Na}^{+}$transport in human red cells: evidence fo $\mathrm{Na} / \mathrm{H}$ exchange system. $\mathcal{J}$ Membr Biol 1986;90:21-8.

55 Jennings ML, Adams-Lackay M, Cook KW. Absence of significant sodium-hydrogen exchange by rabbit erythrocyte sodium lithium countertransporter. Am 7 Physiol 1985;249:C63-8. 6 Weder AB. Red cell lithium-sodium countertransport and renal lithium clearance in hype tension. N Engl f Med 1986;314:198-201.

57 Lever AF. Slow pressor mechanisms in hypertension: a role for hypertrophy of resistance vessed Journal of Hypertension (in press).

\section{Pacemaker syndrome}

Permanent cardiac pacing is the treatment for symptomatic bradycardia due to ventricular conduction defects, sinoatri disease, and the carotid sinus syndrome. About 114 ne pacemakers for every million people are implanted each yeap in Britain, and the rate is increasing. A stable rate of 300-40 per million may be reached nationally over the next five yea $\mathrm{E}$ and has already been approached by a few British centres ane reached in several European countries. ${ }^{1}$ It is increasing important, therefore, that doctors appreciate that apparent satisfactory function of an implanted ventricular pacemaker may be associated with a whole range of cardiac symptome? 
such as dizzy spells, syncope, breathlessness, impaired exercise capacity, and postural hypotension. These symptoms may constitute the "pacemaker syndrome," which once recognised is readily treated.

The syndrome results from atrial contraction occurring during ventricular systole and is a consequence of ventricular pacing. The atria contract against closed atrioventricular valves and produce raised mean pressures in the right and left atria with reduced cardiac output and blood pressure. ${ }^{23}$ The pacemaker syndrome occurs when retrograde atrioventricular conduction is intact and conduction spreads from the paced ventricles to the atria generally through the atrioventricular node; this may happen even when antegrade conduction is blocked. Ventricular pacing competing with sinus rhythm may be similarly symptomatic. ${ }^{45}$ Dual chamber pacing, in which pacing and sensing occur in both the atrium and ventricle, is rarely associated with the pacemaker syndrome because the physiological relation of atrial contraction preceding ventricular contraction is maintained. ${ }^{6}$

Patients with pacemaker syndrome complain of syncope or near syncope, dizziness, chest pain, fatigue, breathlessness, palpitations, and neck pulsations or pressure. Examination may show cannon waves in the jugular venous pulse or palpable liver pulsations. The diagnosis is made by observing or reproducing the adverse haemodynamic effects, signs, and symptoms during ventricular pacing. ${ }^{457}$

Though the incidence of this symptomatic pacemaker syndrome is low, many "asymptomatic" patients have felt better with dual chamber pacing when this has been compared with ventricular pacing by within patient randomised control studies..$^{8-12}$ This is mainly because sequential atrioventricular contraction is restored.

Up to a fifth of patients with preserved retrograde atrioventricular conduction develop symptoms suggestive of the pacemaker syndrome. ${ }^{5}$ Retrograde conduction is present in $40 \%$ of patients with complete antegrade atrioventricular block and $90 \%$ of patients with normal atrioventricular conduction who have the sick sinus or carotid sinus syndromes. ${ }^{13}$ Therefore atrial or dual chamber pacing is best for patients with the sick sinus syndrome ${ }^{11}$ and dual chamber pacing for those with the carotid sinus syndrome. ${ }^{14} 15$

Symptoms of the pacemaker syndrome may be reduced by reprogramming a ventricular pacemaker so that competition between paced and sinus rhythm is minimised by adding rate hysteresis such that pacing starts only after a pause substantially longer than the pacing interval. ${ }^{16}$ The antiarrhythmic agents flecainide and disopyramide are effective in blocking retrograde conduction in patients with pacemakers ${ }^{17}{ }^{18}$ and may ameliorate pacemaker syndrome. Nevertheless, flecainide increases the pacing threshold and requires careful control of pacemaker output. Patients who do not respond to these measures must be upgraded to dual chamber pacing. In new patients who require pacing but retain antegrade conduction and have preserved retrograde conduction the syndrome may be prevented by implantation of a dual chamber pacemaker.

Rose ANNE KenNy Research fellow

RICHARD SUTTON Consultant cardiologist

Cardiology Department,

Westminster Hospital,

London SW1P 2AP

Correspondence to: Dr Rose Anne Kenny.

1 Feruglio GA, Steinbach K. Pacing in the world today. World survey on cardiac pacing for the years 1979 to 1981. In: Feruglio GA, ed. Proceedings of the second European symposium on cardiac pacing. Padua: Piccin Medical, 1982:953-67.
2 Naito M, Dreifus LS, David D, Michelson EL, Mardelli TJ, Kmetzo JJ. Re-evaluation of the role of atrial systole to cardiac hemodynamics: evidence for pulmonary venous regurgitation during abnormal atrioventricular sequencing. Am Heart $\mathcal{F}$ 1983;105:295-302.

3 Naito M, Dreifus LS, Mardelli TJ, et al. Echocardiographic features of atrioventricular and ventriculoatrial conduction. Am f Cardiol 1980;46:625-33.

4 Enlebacher JA, Danner RL, Stelzel PE. Hypotension with ventricular pacing: an atrial vasodepresser reflex in human beings. $\mathcal{F}$ Am Coll Cardiol 1984;5:500-5.

Nishimar RA, Gersh BJ, Vlietstra RE, Osborn MJ, Ilstrup DM, Holmes DR. Hemodynamic and symptomatic consequences of ventricular pacing. PACE 1982;5:903-10.

6 Torresani J, Ebogosti A, Allard-Latour G. Pacemaker syndrome with DDD pacing. PACE 1984 7:1148-51.

7 Haas JM, Strait GB. Pacemaker induced cardiovascular failure: hemodynamic and angiographic observations. Am 7 Cardiol 1977;33:295-9.

8 Kruse I, Arnham K, Conradson TB, Ryden L. A comparison of the acute and long-term haemodynamic effects of ventricular inhibited and atrial synchronous ventricular inhibited pacing. Circulation 1982;5:846-55.

Perrins EJ, Morley CA, Chan SL, Sutton R. Randomised controlled trial of physiological and Perrins EJ, Morley CA, Chan SL, Sutton R. R
ventricular pacing. Br Heart 7 1983;50:112-7.

10 Sutton R, Perrins EJ, Morley C, Chan SL. Sustained improvement in exercise tolerance following physiological cardiac pacing. Eur Heart $\mathcal{f} 1983 ; 4: 781-5$.

1 Mitsuoka T, Kenny RA, Yeung TA, Chan SL, Perrins EJ, Sutton R. Benefits of DDD pacing in sick sinus syndrome. PACE 1985;8:293.

2 Kenny RA, Ingram A, Mitsuoka T, Walsh K, Sutton R. Optimal pacing mode for angina pectoris patients. Br Hearl $\mathcal{F}$ (in press).

3 Morley C, Sutton R, Perrins J, Chan SL. The importance of retrograde atrioventricular conduction in physiological cardiac pacing. In: Feruglio GA, ed. Proceedings of the second European symposium on cardiac pacing. Padua: Piccin Medical, 1982:739-41.

4 Madigan NP, Flaker GC, Curtis JJ, Reid J, Mueller KJ, Murphy TJ. Carotid sinus hypersensitivity: beneficial effects of dual chamber pacing. Am $\mathcal{f}$ Cardiol 1984;53:1034-50.

Morley CA, Perrins JP, Chan SL, McBrien DJ, Sutton R. Carotid sinus syncope. Analysis of persistent symptoms and role of atrioventricular sequential pacing. Br Heart 7 1982;47:411-8.

Morley CA Perrins EJ, Chan SL, Sutton R. The role of rate hysteresis pacing in the hypersensitive carotid sinus syndrome. PACE 1983;6:1224-8.

7 Perrins EJ, Morley CA, Dixey J, Sutton R. The pharmacological blockade of retrograde Pentricular conduction in paced patients. PACE 1983;6:A112.

8 Vardas $\mathrm{P}$, Kalogeropoulos $\mathrm{Ch}$, Kenny RA, Walsh K, Sutton R. The influence of disopyramide on inus node function and atrioventricular conduction in syncopal patients [Abstract]. PACE 1986;9:310a.

\section{Weight gain in pregnancy: eating for two or just getting fat?}

What advice should a doctor give to a woman about her weight during pregnancy? Should he tell her to eat for two, or if she is gaining weight too fast should he advise her to diet? These are everyday questions, but, as so often happens, research has provided some conflicting answers.

The average woman gains $12.5 \mathrm{~kg}$ during pregnancy, though normal women may lose weight or gain over $20 \mathrm{~kg}$. ${ }^{1}$ Much of the increase is accounted for by the uterine contents, enlargement of maternal organs, and-particularly in the third trimester-increased body water. ${ }^{\prime}$ The remainder, averaging about $3.5 \mathrm{~kg}$, is fat. By a mechanism that is not fully understood ${ }^{2}$ pregnancy alters carbohydrate metabolism, ${ }^{3}$ and subcutaneous fat is laid down over the abdomen, back, and upper thighs, mainly in the first and second trimesters. ${ }^{13}$ The fat is usually lost again afterwards-a process aided by lactation ${ }^{4}$ - and for most women long term weight gain is an effect of age rather than parity. ${ }^{13}$ Nevertheless, during pregnancy fat women tend to put on more weight than thin ones. ${ }^{3}$

Women who are overweight at the start of pregnancy face an increased risk of complications. ${ }^{3}{ }^{6}$ Hypertensive disorders are more frequent,,$^{78}$ though the incidence in different reports varies widely-from $7 \%{ }^{9}$ to $46 \% .^{3}{ }^{10}$ Abnormal glucose tolerance is also more common, affecting $7-17 \%$ of obese women. ${ }^{7 \cdot 10}$ Increased risks of urinary tract infections and possibly thrombophlebitis have been reported, ${ }^{8}$ but the risks of anaemia ${ }^{8}$ and preterm delivery ${ }^{11}$ may be lower than in underweight women. Older studies found that perinatal mortality was higher among obese women, ${ }^{312}$ but more recent reports have not confirmed this ${ }^{7}{ }^{10}$; perinatal mortality may have been reduced in these patients because of recognition of the risks and consequent careful supervision. ${ }^{6}$ A recent American study concluded, however, that if 